\title{
Diversity Studies in Onion Genotypes
}

\author{
D. Jeevitha ${ }^{1 *}$, P.R. Dharmatti ${ }^{1}$, R.V. Patil ${ }^{1}$, B.D. Biradar ${ }^{2}$ and M.S. Patil ${ }^{3}$ \\ ${ }^{1}$ Department of Horticulture UAS, Dharwad-580005, India \\ ${ }^{2}$ GPB and UG Dean UAS, Dharwad-580005, India \\ ${ }^{3}$ Plant pathology, Dharwad-580005, India \\ *Corresponding author
}

Ke y w o r d s
Onion, Genotype,
Cluster, Diversity

\section{A B S T R A C T}

\section{Introduction}

Onion is one of the important export earning vegetable crop, which earns nearly 4000 crores foreign exchange annually. It has been cultivated for more than 5000 years in the world. Onion (Allium cepa L.) is monocotyledonous vegetable crop of the family Alliaceace sub-family Allioideae and order Asparagales having chromosome number $2 n=2 x=16$. In India no kitchen is free from onions, it means in each and every home Indians use onion in one or other form everyday hence, it is regarded as "Queen of Kitchen". It is also called by different names Pyaz, Ullagaddi, Eerulli, Neerulli in vernacular languages. The evidence of onion was seen in Chinese gardens, Egyptian pyramids and inner wall of their paintings and also mentioned in Bible. 
The domestication of onion was found in mountainous regions of Turkmenistan and North Iran bordering the ancient advanced civilization of the Near East (Sumerian). Hence, South-West Asia is regarded as being the primary centre of domestication and variability. Other regions of great diversity like Mediterranean are considered as secondary centres (Hanlet, 1990; Fritschan and Friesen, 2002).

Onion contains an enzyme known as Allinase responsible for catalyzing chemical reactions that produce the volatile chemicals which gives good flavor and odor. The pungency is due to volatile oil "Allylpropyl disulphide $\left(\mathrm{C}_{6} \mathrm{H}_{12} \mathrm{~S}_{2}\right)$, the colour of outer skin is due to quercetin, anti fungal factor is due to phenolic compound known as catechol and tear inducing action is due to lachrymator factor i.e., 1-Propenyl sulfonic acid.

The estimation of genetic diversity helps in identifying the genotypes for the hybridization program. The selection of diverse parents for crossing is the first thing to obtain a character of interest in any crop. Some time genotypes with moderate diversity were also chosen to identify the best combinations (Vinutha, 2000). Genetic diversity signifies the differences in gene frequencies. Mahalanobis generalized distance is the most widely used technique in plant breeding to know the distance between the genotypes. This statistical tool has been used extensively by the breeders to resolve genetic divergence at their varietal and species levels in classifying crop plants (Lokhande et al., 1987; Dhotre et al., 2010).

\section{Materials and Methods}

An experiment on "Diversity Studies in Onion Genotypes"'(Allium cepa L. )' was undertaken during 2017 December at the site of All India Network Research Project on
Onion and Garlic, Department of Horticulture, Main Agriculture Research Station UAS, Dharwad. Using randomized complete block design with three replications, spacing followed was $15 \mathrm{~cm} \times 10 \mathrm{~cm}$ and total area of experiment was $900 \mathrm{~m}^{2}$. The experimental material was collected from DOGR and the all the package of practices were carried out as per the recommendation give by DOGR.

Forty five days old seedlings are transplanted in the main field on 5-12-2017, harvested during march 2018. The data recorded for individual character from the selected plants were averaged and means values obtained from this were subjected to simple RCBD analysis then final analysis was done using INDOSTAT developed by Indian Statistical Research Institution, New Delhi.

\section{Results and Discussion}

To achieve success in any crop, adoption of proper breeding programme is must. Analysis of the genetic diversity present in the parents which is foremost important. The significance of genetic diversity in the hybridization programme has long been customary by the breeders. It was commonly found that the extent of heterosis exhibited by a hybrid is a function of genetic divergence between the parents. The Mahalanobis $\mathrm{D}^{2}$ statistics is a valuable tool in obtaining a quantitative assessment of divergence which measures the forces of contrast at intra and inter-cluster levels.

The genetic diversity was studied to know the extent of genetic divergence among fifty-six onion genotypes for fourteen characters. The diversity was determined by using Mahalanobis $\mathrm{D}^{2}$ statistics. It also helped to know the relative distances between these genotypes for the characters under study. The results are based on the $\mathrm{D}^{2}$ values and 
indicated that there was adequate diversity among the genotypes. Analysis of genetic divergence has been used to quantify the genetic distance between the genotypes and to identify the promising ones to initiate crossing programme to generate hybrids with desirable character (Table 1 and 2).

\section{Composition of clusters}

Fifty-six genotypes distributed in 6 clusters based on $\mathrm{D}^{2}$ values. Cluster I includes the maximum number of genotypes i.e., fortyeight, cluster IV has two genotypes, cluster VI has three genotypes cluster II, III and V are solitary clusters because these clusters have only one genotype in it (Table-4 and Fig. 1).

\section{Inter and intra- cluster distances}

Fifty-six genotypes differed significantly for inter-cluster and intra-cluster values and formed six clusters. The average values ranged from 0 to 630.05 . The highest intracluster distance was noticed in cluster VI (630.05) and the lowest was observed in clusters II, III, and V (0) respectively.

The maximum inter-cluster values (4700.71) were noticed between the cluster III and VI, where minimum inter-cluster distance was obtained between the cluster II and III (195.06) respectively.

\section{Cluster means for various parameters in onion genotypes}

Cluster means analysis of 56 onion genotypes for 15 characters were worked out and presented in the table-4. Cluster means for different parameters under study indicated that, the considerable genetic divergence between the groups, which indicated the significant differences for the characters studied. Mean values for growth parameters viz., plant height $(60.98 \mathrm{~cm})$, leaf number (7.17) and neck thickness $(0.97 \mathrm{~cm})$ were noticed highest in genotype present in the cluster III and it was lowest plant height $(37.66 \mathrm{~cm})$, leaf number (5.47) and neck thickness $(0.70 \mathrm{~cm})$ was noticed in the genotype of the cluster IV respectively.The genotypes of cluster III also exhibited the highest equatorial bulb diameter $(6.17 \mathrm{~cm})$, polar bulb diameter $(5.90 \mathrm{~cm})$ and it was significantly lowest in the genotype present in cluster II $(3.49 \mathrm{~cm})$. Highest mean values for bulb weight (79.39), marketable yield 50.44, and total yield 54.90 were found in cluster V and the lowest values for these parameters were recorded in the cluster I, bulb weight (46.22). Cluster II had lowest marketable yield (31.00) and total yield (36.57).

Mean values for total soluble solids were noticed highest in cluster II i.e., 13.22 and it was recorded lowest in the cluster $\mathrm{V}$ i.e., 11.42 respectively.

Mean values were low in the cluster III for purple blotch (2.00) and thrips (1.33) incidence and highest in cluster IV for purple blotch and 2.50 thrips (2.67). Storage is one of the important characters which decides the utilization of genotypes in further breeding programme. Cluster III registered lowest total weight loss (12.57), rot loss (5.67) and sprout loss (7.00) and highest mean values were obtained for total weight loss (53.15), rot loss (19.53) and sprout loss (19.20) in the cluster I.

Mean values for days taken to harvest was lowest in the genotypes of the cluster II and III (106.67) which implies that these genotypes are early because these took a less number of days for harvesting compared to the genotypes of other clusters. 
Table.1 List of genotypes used in diversity study

\begin{tabular}{|c|c|c|c|}
\hline Sl. No. & Genotypes & SI. No & Genotypes \\
\hline 1 & Col-819 & 29 & Bhima Safed \\
\hline 2 & IHR-AKS-30 & 30 & Bhima Shubra \\
\hline 3 & IHR-AKS-35 & 31 & DOGR-1606 \\
\hline 4 & L-883 & 32 & W-344 \\
\hline 5 & JRO-07-17 & 33 & DOGR-1605 \\
\hline 6 & Bhima Super & 34 & DOGR Hyb-8 \\
\hline 7 & RO-645 & 35 & DOGR-KHM-4 \\
\hline 8 & RO-654 & 36 & DOGR-361 \\
\hline 9 & Sel-153-1 & 37 & BSS-262 \\
\hline 10 & L-857 & 38 & GKD-75 \\
\hline 11 & Bhima Red & 39 & Bhima Dark Red \\
\hline 12 & DOGR-361 & 40 & GKD-45 \\
\hline 13 & PYO-102 & 41 & Rampur local \\
\hline 14 & RGP-2 & 42 & PKV White \\
\hline 15 & Jindhal Pune Fursangi & 43 & PRO-7 \\
\hline 16 & Oriental hybrid & 44 & Jindal Riva \\
\hline 17 & Indam-4-F1 & 45 & JWO-11-5-7 \\
\hline 18 & DOGR Hyb-6 & 46 & GAWO-2 \\
\hline 19 & DOGR-344 & 47 & DOGR-White -Hyb-2 \\
\hline 20 & L-849 & 48 & RGP-2 \\
\hline 21 & L-355 & 49 & DOGR Hyb-5 \\
\hline 22 & Bhima Kiran & 50 & L-359 \\
\hline 23 & RGP-4 & 51 & GKD-78 \\
\hline 24 & Pune Red & 52 & PCH-3 \\
\hline 25 & Arka Kalyan & 53 & RGP-3 \\
\hline 26 & RGP-1 & 54 & PCH-5 \\
\hline 27 & Bhima Sweta & 55 & GKD-3 \\
\hline 28 & GKD-42 & 56 & Bhima Shakti \\
\hline
\end{tabular}


Table.2 Average intra (With in) and intercluster (between) $\mathrm{D}^{2}$ values of onion genotypes.

\begin{tabular}{|c|c|c|c|c|c|c|}
\hline Cluster & I & II & III & IV & V & VI \\
\hline I & $\mathbf{5 3 0 . 0 3}$ & 811.57 & 922.67 & 1150.79 & 797.56 & 3411.18 \\
\hline II & & $\mathbf{0}$ & 195.06 & 752.25 & 828.74 & 4007.49 \\
\hline III & & & $\mathbf{0}$ & 839.1 & 934.89 & $\mathbf{4 6 0 0 . 7 1}$ \\
\hline IV & & & & $\mathbf{1 1 1 . 7 6}$ & 1107.53 & 3960.62 \\
\hline V & & & & & $\mathbf{0}$ & 1667.8 \\
\hline VI & & & & & & $\mathbf{6 3 0 . 0 5}$ \\
\hline
\end{tabular}

*Diagonal values indicates intra-cluster distance and above diagonal values indicates inter-cluster values

Table.3 Per cent contribution of 56 genotypes to total divergence kharif

\begin{tabular}{|c|c|c|c|}
\hline SI. No. & Character & \% Contribution & Rank \\
\hline $\mathbf{1}$ & Plant height $(\mathrm{cm})$ & $3.44 \%$ & VI \\
\hline $\mathbf{2}$ & Number of leaves & - & - \\
\hline $\mathbf{3}$ & Neck thickness $(\mathrm{cm})$ & - & - \\
\hline $\mathbf{4}$ & Equatorial diameter(cm) & $.78 \%$ & VII \\
\hline $\mathbf{5}$ & Polar diameter(cm) & $.58 \%$ & VIII \\
\hline $\mathbf{6}$ & Average bulb weight $(\mathrm{g})$ & $15.39 \%$ & III \\
\hline $\mathbf{7}$ & Total soluble solids(brix) & $.06 \%$ & $\mathrm{X}$ \\
\hline $\mathbf{8}$ & Marketable yield t/ha & $8.51 \%$ & IV \\
\hline $\mathbf{9}$ & Total yield t/ha & $.19 \%$ & IX \\
\hline $\mathbf{1 0}$ & Purple blotch & $.06 \%$ & $\mathrm{X}$ \\
\hline $\mathbf{1 1}$ & Thrips incidence & - & - \\
\hline $\mathbf{1 2}$ & Total weight loss $(\%)$ & $44.48 \%$ & I \\
\hline $\mathbf{1 3}$ & Total sprouts number & $22.6 \%$ & II \\
\hline $\mathbf{1 4}$ & Total Rot Number & $.06 \%$ & $\mathrm{X}$ \\
\hline $\mathbf{1 5}$ & Days taken for harvest & $3.83 \%$ & V \\
\hline
\end{tabular}


Table.4 Cluster means for important characters kharif

\begin{tabular}{|l|l|c|l|l|l|l|l|l|l|l|l|l|l|}
\hline $\begin{array}{l}\text { Sl. } \\
\text { No. }\end{array}$ & Cluster & $\begin{array}{l}\text { Number of } \\
\text { genotypes }\end{array}$ & $\begin{array}{l}\text { PH } \\
(\mathbf{c m})\end{array}$ & NOL & $\begin{array}{l}\text { NT } \\
(\mathbf{c m})\end{array}$ & $\begin{array}{l}\text { ED } \\
(\mathbf{c m})\end{array}$ & $\begin{array}{l}\text { PD } \\
(\mathbf{c m})\end{array}$ & $\begin{array}{l}\text { ABW } \\
(\mathbf{g})\end{array}$ & $\begin{array}{l}\text { TSS } \\
(\mathbf{B r i x})\end{array}$ & $\begin{array}{l}\text { MY } \\
\mathbf{t} / \mathbf{h a}\end{array}$ & $\begin{array}{l}\text { TY } \\
\text { t/ha }\end{array}$ & $\begin{array}{l}\text { TWL } \\
(\mathbf{\%})\end{array}$ & DTH \\
\hline $\mathbf{1}$ & I & 48 & 50.25 & 5.87 & 0.78 & 5.18 & 4.74 & $\mathbf{4 6 . 2 2}$ & 13.14 & 34.98 & 38.71 & 53.15 & 108.26 \\
\hline $\mathbf{2}$ & II & 1 & 57.50 & 5.67 & 0.95 & 5.63 & 3.43 & 51.15 & $\mathbf{1 3 . 2 2}$ & $\mathbf{3 1 . 0 0}$ & $\mathbf{3 6 . 5 7}$ & 14.07 & 106.67 \\
\hline $\mathbf{3}$ & III & 1 & 60.98 & $\mathbf{7 . 1 7}$ & 0.97 & $\mathbf{6 . 1 7}$ & $\mathbf{5 . 9 0}$ & 52.80 & 12.60 & 34.40 & 39.25 & $\mathbf{1 2 . 5 7}$ & 106.67 \\
\hline $\mathbf{4}$ & IV & 2 & 37.66 & 5.47 & 0.70 & 5.40 & 5.00 & 47.63 & 13.05 & 37.40 & 39.50 & 25.71 & 108.83 \\
\hline $\mathbf{5}$ & V & 1 & 54.61 & 5.52 & 0.97 & 6.11 & 5.40 & 79.39 & $\mathbf{1 1 . 4 2}$ & $\mathbf{5 0 . 4 4}$ & $\mathbf{5 4 . 9 0}$ & 1.00 & 112.67 \\
\hline $\mathbf{6}$ & VI & 3 & 56.05 & 6.49 & 0.60 & 5.38 & 4.42 & 48.08 & 13.18 & 51.03 & 56.19 & 2.00 & 114.78 \\
\hline
\end{tabular}

Note: Plant height $(\mathrm{cm})$, Number of leaves, Neck thickness $(\mathrm{cm})$, Equatorial diameter $(\mathrm{cm})$, Polar diameter $(\mathrm{cm})$, Average bulb weight (g), Total soluble solids $\left({ }^{\circ}\right.$ brix $)$, Marketable yield ( $\left.t / h a\right)$, Total yield ( $/$ ha), Total weight loss $(\%)$

Fig.1 Average intra (With in) and inter-cluster (between) $D^{2}$ values of onion genotypes

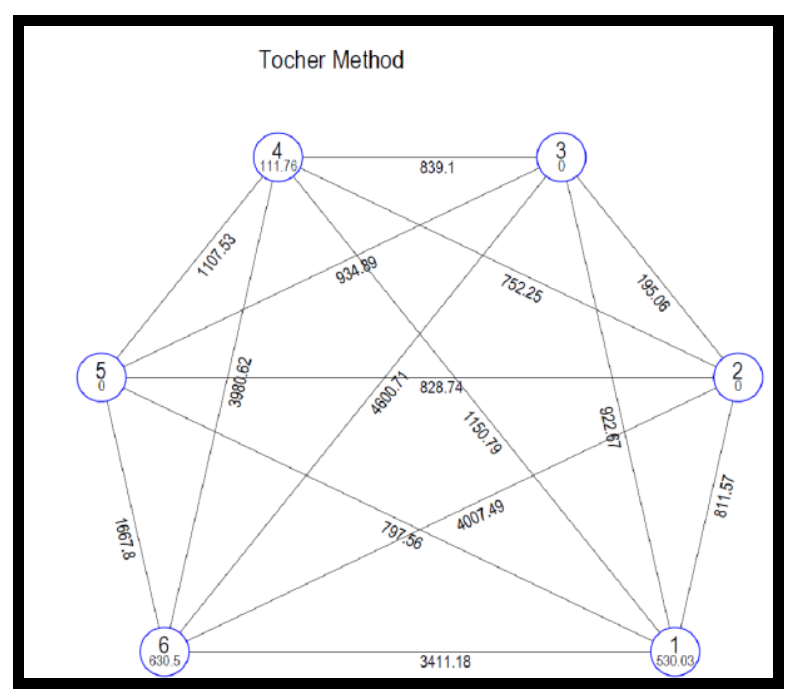

GKD-3, Bhima Shakti, Bhima Dark Red, GKD-42, Arka Kalyan, Bhima Super, RGP-1, GKD -75 these genotypes present in the cluster II, III, IV, V, and VI showed variation for growth, yield and storage characters. By utilizing these genotypes in the hybridization program, we can improve the growth, yield and quality of onion.

\section{Per cent contribution of different characters for total divergence}

The character which appeared first in the rank and its contribution towards total divergence are presented in table 3 .
Among all the characters, total weight loss was ranked first which contributed (44.48\%) to total divergence taking 685 times out of 1540 combinations, followed by total sprouts number $(22.60 \%)$ contributing 348 times out of 1540 combinations. Average bulb weight $(15.39 \%) 237$ times, marketable yield (8.51\%) 131 times, days taken for harvest (3.83\%) 59 times, plant height (3.44\%) 53 times, equatorial bulb diameter $(0.78 \%) 12$ times, the polar bulb diameter $(0.58 \%) 9$ times, Total rot loss number and total yield contributed $(0.19 \%) 1$ time respectively. On contrary to this there was no contribution from the traits like thrips incidence, neck 
thickness, and the number of leaves to the total divergence in onion genotypes.

Onion (Allium cepa L.) is one of the leading commercial export-oriented crops of India which contribute 70 per cent to production. Till today many varieties have been released across the country by various research institutions, private companies in large number but fail to meet the demand. Most of the released varieties also lack in most expected parameters such as uniformity in shape and color, number of bolters and splits, susceptibility to diseases, and poor shelf life.

This is possible by clustering the germplasm trails based on $\mathrm{D}^{2}$ values, as it represents the index of genetic diversity among genotypes and clusters. Based on the $\mathrm{D}^{2}$ values, 56 genotypes were grouped into six clusters. There were 48 genotypes in the cluster I and two genotypes present in cluster IV. In the cluster, VI had three genotypes, while clusters II, III, and V were solitary ones.

The formation of a solitary cluster may be due to the total isolation, preventing the gene flow or intensive natural or human selection for diverse adaptive complexes. The intra-cluster distance varies from 0 in clusters II, III, and IV and the maximum distance was noticed in cluster VI (630.05). This indicates the presence of divergent genotypes within different clusters. Patil (1983)

The inter-cluster $\mathrm{D}^{2}$ values also ranged widely with a minimum value of 195.06 between clusters II and III and maximum inter-cluster distance was noticed in between cluster III and VI 4600.67 indicating high diversity among the genotypes. Cluster IV with two genotypes (Bhima Dark Red, GKD-42), cluster VI with three genotypes (Arka Kalyan RGP-3 GKD -75) cluster II, III V has single genotypes in them these were the most divergent groups. It is desirable to select accessions from clusters showing high inter- cluster distance. All most all the clusters showing high to a moderate value of diversity. Among the eighteen characters studied, the most important character contributing to the divergence was total weight loss followed by total sprouts. Similar results were noticed by Vinutha (2000), Panthee et al., (2006) and Yadav et al., (2018) in garlic. Mohanty, (2001) also reported the highest contribution from bulb weight. Whereas, Patil (1997) reported that ten bulb weight, marketable bulb per cent and loss due to sprouting were the characters that exhibited maximum contribution towards the diversity in onion. Ningadalli (2006) reported that bulb yield, bulb weight, number of leaves, and storage loss were the maximum contributing characters towards genetic diversity. Dhotre et al., (2010) reported that fresh bulb weight, equatorial bulb diameter, bulb splitting, bulb yield total loss as the maximum contributing characters towards genetic diversity these types of results were also observed in our study.

In conclusion, fFifty six genotypes were used to study the genetic diversity using Mahalanobsis $\mathrm{D}^{2}$ statistics and it was found that GKD-3, Bhima Shakti, Bhima Dark Red, GKD-42, Arka Kalyan, Bhima Super, RGP-1, GKD -75 these genotypes present in the cluster II, III, IV, V, and VI and lines L-883, Pune Red, L-863, DOGR-344, L-355, Bhima Kiran, PRO-7, RGP-2, RGP-3, present in the cluster I exhibited moderate diversity. Hence, these can be utilized as lines in hybridization programme for improving growth, yield and storage characters.

\section{References}

Dhotre, M., Alloli, T. B., Kulkarni, U. K. and Athani, S. I., 2010, Genetic diversity studies in kharif onion (Allium cepa L.). Karnataka. J. Agric. Sci., 23 (5): 811812.

Hanlet, P., 1990, Onions and Allied crops, 
botany, physiology, and genetics, CRC Press, Boca Raton, Florida, USA.

Mohanty, B. K. and Prusti, A. M., 2001, Genetic diversity of the cultivars of garlic (Allium sativum L.) for molecular marker RAPO. Jawahar Nehru Krishi Vishva Vidyalaya. Res. J., 34(1-2): 1519.

Ningadalli, M., 2006, Heterosis and combining ability studies in onion. $M$. Sc. (Agri.) Thesis, Univ. Agric. Sci., Dharwad. Karnataka (India).

Panthee, D. R., Regmt, H. N., Subedi, P. P., Bhattarai, S. and Dhakal, J., 2006, Diversity analysis of garlic (Allium sativum L.) germplasm available in Nepal based on morphological characters. Gen. Res. Crop Eval., 53(1): 205-212.
Patil, P. S., 1997, Genetic variability and diversity in onion (Allium cepa L.). M.Sc. (Agri.) Thesis, Uni. Agric. Sci. Dharwad. Karnataka, (India).

Vinutha, B., 2000, Heterosis in relation to parental diversity in onion (Allium cepa L.). M. Sc. (Agri.) Thesis. Univ. Agric. Sci., Dharwad, Karnataka, (India).

Yadav, V. P. S., Maurya, P. R., Sriom and Kumar, S., 2018, Studies on genetic divergence in garlic (Allium sativum L.) germplasm. J. Pharmacogn. Phytochem., 7(6): 1625-1630.

Lokhande, G. D., Pawar, B. B. and Dombre, A. D., 1987, Genetic divergence in garlic. Current Research Reporter, Mahatma Phule Krishi Vidyapeeth, 3: 98-99.

\section{How to cite this article:}

Jeevitha, D., P.R. Dharmatti, R.V. Patil, B.D. Biradar and Patil, M.S. 2020. Diversity Studies in Onion Genotypes. Int.J.Curr.Microbiol.App.Sci. 9(10): 3051-3058. doi: https://doi.org/10.20546/ijcmas.2020.910.367 